\title{
The Russian Empire of the Wane Period: Learned Elites and Authority
}

\section{Paul L. Karabushenko}

Astrakhan state university

\section{Arushan A.Vartumyan}

Pyatigorsk State Linguistic University

Email: sci.publ@gmail.com

\section{Doi:10.5901/mjss.2015.v6n4s2p696}

\section{Abstract}

The greatness of any empire is composed of the diversity of structural factors among which a special position is taken by the quality of science and education development. This factor is vividly revealed in the learned elite and their relationships with the authorities. Every empire has its own experience of the learned elite and authorities relations, its own cultural traditions and scientific novelties. The Russian learned elite of the Russian autocracy's last existence decades shows us the rise in scientific thought and cultural activities. Not without reason, this period of time is called Silver Age of the Russian culture. That rise was broken by the Russian revolution to have thrown the scientific thought development in Russia back for decades. The present paper deals with the examination of those characteristics.

Keywords: scientist, learned elite, authorities, elitist education, personality, creative work, personalism, Russian monarchy

\section{Introduction}

Traditionally the learned elite has been defined as the summit and pride of the scientific thought. Those who have made great contribution to the scientific knowledge and who are enlisted in the academic annals and have become a respected authority in his/her academic field are reckoned among the learned elite. Every elite personality is backed by the particular biography to be the record of his/her scientific achievements unveiling us the secrets of their creative workshop, a thorny recognition path, a struggle of the ideas proposed, etc. As we see it, the learned elite is the most advanced creative minority whose obligation is to produce unique ideas; search for the adequate response to their epoch's challenges; createthe spiritual "safety net".

Science and its elite is such a particular activity that it cannot be compared with any other one. The subject of the learned elite is an absolute intellectual creative self-sufficiency, it is a "thing in itself"("chose ensoi; cosa in se"). A scientist as a "thing in itself" possesses complete independence and urge of other people to understand his/her creative work, to discover his/her initial intentions.

In this respect, he/she turns out to be a phenomenon which can make an impact, and which they have to take into consideration due to its specific importance.

While objectively evaluating the mental capabilities of the imperial elite of the RE's last existence decades, we can confidently say that there were all sorts of them. The value of the intellect disappears (depreciates) in the face of the true superb mind which critically evaluates the gift of the lower-level people. Many questions especiallycould be given to the civil servants who tried to control the development of science and education.

As a rule, the representatives of the learned elite studied at the classical educational institutions (a gymnasium, a university) and after that, they revealed their unique capabilities defending their dissertations. It was always a systems approach that was implemented in the scientific capabilities. At the same time, every personality represented an individually functioning system fitting in the general system of the Russian science. Each system was so self-sufficient, so much it required to become elite.

\section{Research Methodology}

The period at the turn of $19^{\text {th }}$ and $20^{\text {th }}$ centuries covers the epoch of the Russian Empire (RE) fall when the cultural and 
political-economical crisis was being formed. In the end, that crisis resulted in the terror of the Russian revolution of 1917. The main aim of our present project is to show who reigned and how he ruled Russia at that time and why the consequences of that reign turned out to be so drastic. The subject of our investigation is the representatives of imperial Russia's learned elite of that period. The theme said states the choice of the investigation methods. Historical comparative studies allow us to compare the qualities of the elite and the biographical method used in the study helps not just delve into the private life details but to unveil the secrets of the outstanding learned personality's creative workshop. To analyze the latter we also turn to the methods of the Russian personalism (N.A. Berdyaev) and hermeneutics (G.G. Shpet). The authors of those methods themselves represented the learned elite of their time.

\section{Analysis Result}

Learned elite: Russian family traditions. The Russian science as a sponge absorbed the most valuable things from the European experience. No doubt, the Europeans were teachers for the Russian scientists. With time, the partition between European and Russian segments began to disappear just owing to the fact that the European scientific thought having come to Russia became Russian here and the Russian scientific thought turned to be European. The integration of minds is the most complicated but at the same time, the most desirable system-forming force. The university education itself was making foundations of the future learned elite. By the second half of the $19^{\text {th }}$ century Russian proprietary university traditions had already been formed, the experience in self-reproduction of the learned elite having been accumulated. The majority of the learned elite were found in higher educational institutions of Russia. The universities of Moscow, Saint-Petersburg, Kazan appeared to be the gravitation epicenter for the advanced scientific thought of that time. To "grind" their qualification, many Russian scientists had to take internships abroadstudying the foremost current European thought. Such a practice had become a tradition in the pre-revolutionary decades of Russia's history giving evidence of the openness of the whole system.

Natural geniuses were quite many In Russia. They came from both lower classes of the society and from the nobility and intelligentsia. At that time, such great scientific discoveries were made in Russia as: in 1876 the first in the world electric lamp (P.N. Yablochkov) [Edison's lamp was lit in 1878], in 1879 the first in the world gasoline engine (S.O. Kostovich), cracking to process oil into light distillates (V.G. Shukhov), in 1906 the first in the world automatic rifle (V.G. Fedorov) and at last, the first in the world woman - professor (S.V. Kovalevskaya, 1884), in 1894 the radio was invented (A.S. Popov) [G. Marconi patented his invention in 1895 though

prior to this in $1891 \mathrm{~N}$. Tesla theoretically proved this principle]. Those were world-scale inventions. It is a different matter that the local authorities did not pay any attention to the inventions and the business people did not see any commercial benefit. It is those two things that are responsible for the mishap of the Russian learned elite: the authorities do not see and the business people do not take any notice.

Special attention should be paid to the patronage, which was well developed. One of the top patrons of that time was the largest Russian financier and manufacturer, the manager of Russia's State Bank (1860 - 1866) baron A.L. von Stieglitz (1814 - 1884). He supported education, art and science with his numerous donations. He donated one million rubles to establish the central technical drawing school. It is known that the State Secretary of the Russian Empire A.A. Polovtsev(1832 - 1909) once wrote in his diary: "Russia will be happy when merchants will make donations for education and academic purposes not hoping to be awarded with the medal". (Polovtsov, 2005) He also spent large funds on charity and education causes. For example, the Russian Biographic Dictionary had been published since 1896 at his expense. In passing, it should be noted that A.A. Polovtsev was married to baron A.L. von Stieglitz's adopted daughter N.M. Iyuneva (a bastard child of Grand Duke Mikhail Pavlovich) that is why he himself had the patrons in the higher classes of the Russian society.

At that time, the genre of academic biographies started evolving in Russia. The personalities of some outstanding scientists made such an impact on their apprentices and followers that the latter wrote excellent memoirs where invaluable records of learned elite's creative activities were described. Among those texts is the volume of collected papers of the great $19^{\text {th }}$ century Russian philosopher V.S. Solovyov (Velichko, 1902)

Quite often, the representatives of the learned elite were mentioned in "Memories" written by the Minister of Finance (1892 - 1903) and Chairman of the Russian Empire Ministers Committee (1903 - 1906) count S.Yu. Vitte(1849 1915). In his younger years, he took thorough studies of mathematics and he even was awarded with Candidate of Sciences title (Vitte, 1994) Having chosen the civil servant career, he preserved interest to his first occupation of a scientist throughout all his life. He always gave a mention of those who possessed a scientific degree or teaching experience. D.I. Mendeleev was one of S.Yu. Vitte's subordinates and who was complimentarily praised by the count. The descriptions of several representatives of the Russian learned elite made by S.Yu. Vitte undoubtedly have historical 
value and give an example of the deep elite observation. (Vitte, 1994). Such observations are quite numerous in the memoir literature of those years. Moreover, many politicians urged to become famous not only in their civil service field but also in science. Many Russian aristocrats were dragged people and spent time on their hobby. For instance, the Russian Empire Foreign Affairs Minister (1895 - 1896) prince A.B. Lobanov-Rostovsky(1824 - 1896) and Secretary of State A.A. Polovtsev "strived to tie their names with the phalange of the Russian historiography" (Vitte, 1994).

The Russian science established family relationships with the Russian culture similarly to the way the nobility contracted marriages with the political class. Silver Age of the Russian culture is an amazing combination of literature, philosophy and science when a gifted personality could successfully take studies in literature, philosophy and science (V.S. Solovyov). Entire learned dynasties emerged which alloyed the scientific thought with art and broadened the horizons of the society's moral life. It was exactly learned elite responsibility to draw learning horizons apart, to provide the strategic mankind's security against the possible degradation tendencies.

There were families specializing in research and culture activities having reached peaks in those activities. Every such family was an original centre of the Russian culture. We can find in such a family several generations of culture and science figures whose names are integral with Russia's history. The most famous example is the family of history professor S.M. Solovyov in Moscow.

The children in those families learned to walk, speak and read simultaneously. Professor S.M. Solovyov's children had actually become the golden property of Russia. His elder son Vsevolod(1849 - 1903) was a well-known novelist, author of historical novels and chronicles. Younger son Vladimir (1853 - 1900) was an outstanding Russian philosopher, historian, poet, publicist, literary reviewer having played an important part in the development of Russian philosophy and poetry of the end of $19^{\text {th }}$ - beginning of $20^{\text {th }}$ century. Daughter PoliksenaSergeevna(1867 - 1924) was a poet and artist. $[16$, p.39-53] It should be noted, that S.M. Solovyov'sstudent V.O. Kluchevsky- who was let into the house and who was a close contact - had become an outstanding historian. Elite personalities draw similar to them people. By the example of the Russian learned elite development, this thesis turns out to be absolutely true.

Russian cultural elite of that time accumulated family relationships. The elite's cultural circle of contacts was narrow. Everybody was somebody's close or distant relative or acquaintance. So, professor D.I. Mendeleev's blood ties were linked with the Russian poetry: he was poet P.P. Yershov's (author of "The Humpbacked Horse") son-in-law married to his stepdaughter in his first marriage and father-in-law of another great poet A. Blok, who was married (1903) to D.I. Mendeleev's daughter Lubov (1881 - 1939), an actress and Russian ballet historian (Blok, 1987). She was the prefiguration of "Fair Lady" of Alexander Blok.

Studying the biographies of many outstanding culture and science figures, suggests that an occasion plays important part in the development of Russian spirituality. If it were not parents' persistence, many geniuses might have not been even born. For example, D.I. Mendeleev - "godfather to chemistry" was the last, seventeenth child in the family (among seventeen children, eight died being infants). This example proves that parents should not stop at the success peak point. The last efforts are always rewarded for by the genius of their posterity.

The biographies of some Russian scientists remind us of the Russian saints' hagiography. So many hagiographies describe future saints' early craving for holy life and rejection to deal with their peers due to their moral backwardness. V.S. Solovyov's biographers write the following about his early age: "The child did not need and did not seek friendship with his peers since he outgrew them spiritually much earlier; but he treated the environment with such exceptionally sensitive and susceptible manner that he even gave proper names to the inanimate objects. He called Grishahis favourite school bag and his pencil that he usually carried on the long lace over his shoulder as if it were a sword or on the neck was called it Andryusha. This childish trait appeared in one of his fundamental philosophic concepts and thus are to be paid special attention to" (Velichko, 1902). However, V.S. Solovyov can be considered to be an exception from this rule since all his life was similar to monk's ascesis.

Prince P.A. Kropotkin - graduate of Page Corps - kept memories of his studies. He especially liked geography and plotting maps in particular. Cartography had become a swan song for him. He knew many maps by heart and while being "in the scantily lit casemate of Peter-and-Paul Fortress he was drawing [the maps] arty" (Kropotkin, 1966). Prince with pleasure reminisced that considerable attention in Page Corps was paid to the field topographic practice, which required good knowledge of geometry, astronomy and mathematics (Kropotkin, 1966).

Many prominent Russian politicians in their younger years were not good at schooling. Some of them behaved badly and violently and had a dashing mental set. While recollecting after many years their luckless experience in schooling, they most often stressed the importance of self-education and inclination for independent studying of that field which later become their professional sphere. For instance, in 1836 the would-be Minister of Internal Affairs of the Russian Empire (1880-1881) Mikhail Loris-Melikov(1825 - 1888) was enrolled in Moscow LazarevOriental Languages Institute and he was expelled from it for disorderly conduct (Shilov, 2002). 
In forty one year however, he turned into cavalry general (17.04.1875) and then honorary member of Imperial Academy of Sciences. (29.12.1880). (See: Kostanyan, 2005, Shilov, 2002). Another outstanding politician of the late 19th - beginning of $20^{\text {th }}$ century count S.Yu. Vitte reminisced that in his childhood he could easily get out of the window at the lesson at gymnasium, which was attended by him irregularly and unwillingly (Shilov, 2002).

Learned elite and tsarist regime: positive and negative experience. The system was rejecting the most prominent figures due to their political unreliability. Protest sentiment turned the dialogue with the authority into the conflict, which most often ended in prison, exile or migration. Considerable number of beginner scientists and philosopherswho demonstrated their political independence, had been in exile (N.A. Berdyaev, P.B. Struve, etc.).

Involvement in social activism set the young promising scientists back their scientific career. The best example to this is the father of the Russian scientific anarchism prince P.A. Kropotkin. His arrest on March 22, 1874 and imprisonment in Peter-and-Paul Fortress had become the turning point in the career of that revolutionary anarchist. However, the little known fact is that on the eve, on Friday March 21, 1874 P.A. Kropotkin made a sensational report at the session of the Geographic Society on the glacial age in the near past ("Investigation of the Glacial Period"). In that paper he gave explanation of the causes of the ancient glaciation, its boundaries and the way glaciers were shaping the relief of Europe spreading fromScandinavia. Today this paper is considered to be a classical one. The value of P.A. Kropotkin's contribution in science was so substantial that by the personal tsar's order he was provided with a pen, paper and an opportunity to work. It was in the prison where he wrote "Investigation of the Glacial Period" proving the glacial theory to have become one of the most important theories in the Earth sciences (Kropotkin, 1876)

The paradox of the situation is that when this paper was published in 1876, its author was an imprisoned political offender.

It should be added that among those who were imprisoned in Peter-and-Paul Fortress we find a historian N.I. Kostomarov (1817 - 1885) who served his one-year term for his panslavic dreaming and a would-be associate of the Russian Empire Finance Minister (1900-1902) V.I. Kovalevsky (1848 - 1934) who in his youth also served for one year in the casemates for his revolutionary activism. The term of twenty three years (1882 - 1905) was served by N.A. Morozov a would-be prominent Soviet academician (Serpokry, 1969). Many outstanding Russian scientists N.K. Mikhailovsky (1882, 1891), P.B. Struve (1901), N.A. Berdyaev (1897-1899) and others were sent in exile "in the middle of nowhere" from Moscow several times. Nevertheless, those preventive measures cannot be compared with those repressions, which in the 1930-1940s Stalinism would unwind against the people and civil elite. The Russian autocracy's preventive measures looked "dreamlike liberalism" (this is what the Russian Empire Minister of Internal Affairs M.T. Loris-Melikov was reproached for at that time) (Lyashenko, 2012), against $20^{\text {th }}$ century totalitarianism.

In 1897, the most famous $20^{\text {th }}$ century Russian philosopher N.A. Berdyaev was arrested, expelled from the university and sent in exile to Vologda. In 1899 student S.L. Frank (an uncle to 1958 Nobel Prize winner I.M. Frank) was arrested and sent in exile from the university towns. Even trustworthy philosophers brothers S.N. and Ye.N. Trubetskoys at the time of the first Russian revolution adhered to the cadet political views.

A scandalous attitude to the Russian authorities and Russia in general, was demonstrated by prince-outcast P.V. Dolgorukov (1816 - 1868) who being in exile published a series of libelous papers on the history of the Russian autocracy. Russia was painted in such black colours (Memoirs of Prince Peter Dolgorukov, 2007) in his memoirs that this surprised and even shocked the major critic of tsarism of that time A.I. Gertsen. Before quitting Russia, P.V. Dolgorukov became famous for publishing several volumes of "Russian Genealogical Collected Stories") where the historical evaluation to aristocracy and nobility was given.

However, there were scientists greatly respected by the authorities. The latter engaged professionals integrating those in the managerial and cultural environment. Many high-rank officials were awarded with scientific degrees and were elected in Academy of Sciences. There were quite many well-known scientists who taught the tsar's family, e.g. historian V.O. Kluchevsky, landscape and sea-scapes painter A.P. Bogolubov (1824 - 1896).

At one time the post of the Finance Minister was taken by two genuine mathematicians I.A. Vyshnegradsky (1887 1892) and S.Yu. Vitte(1892 - 1903). Several rectors of the largest universities were represented by the famous Russian scientists: N.I. Lobachevsky, S.M. Solovyov, V.O. Kluchevsky, S.N. Trubetskoy.

In this connection, the elections of the first rector of Imperial Moscow University on September 2, 1905, when the autonomy was returned to the university, were quite noteworthy. On that day, 43-year old prince, professor S.N. Trubetskoy was elected to the post of rector. He had great authority and respect with his colleagues. On September 22, S.N. Trubetskoy made a decision to close the university because of the students' unrest but this only worsened the situation. In 27 days, on September 29 he had cerebral hemorrhageand died in the Ministry of Public Education (Maslin, 1997)

Scientists' reflection on the role of science in the life of society is also of interest. For example, academician K.A. 
Timiryazev (treated kindly by both the tsarist and Soviet government) believed that "Poet's creativity, philosopher's dialectics, explorer's skill are the materials which make a great scientist" (Timiryazev, 1926). His other idea is "Science cannot move in one or other direction on demand; it studies only what is ripen at the moment, what investigation methods have been worked out for...Science always goes its own way scattering countless precious applications and only absolute shortsightedness can catch the applications not taking notice of where they are falling" (Timiryazev, 1926).

The recognition of the learned elite. As rule,those who represented the elite were notable for the high degree of originality, which attracted the public attention. However, this originality could also produce a negative effect and even be ruinous. The person becomes popular at that time when he is much spoken about in the stories he supposedly took part in. The genre of such stories is called historical joke. In parody science there is a pool of pseudoscientific stories where love or critical evaluation of a scientist's activity is revealed. Often scientists themselves are the authors of such mythologemes. Originality means going beyond the frame of regularity, demonstration of one's individuality and independence.

Outstanding figures had their own strangeness and oddity features arousing surprise in the society. An example of this is philosopher's V.S. Solovyov's interest in turpentine. One of his biographers reminisced: "The room where he lived was filled with the smell of turpentine. V.S. Solovyov thought the substance possessed both mystical and curing effect. He believed that turpentine was a good preventive measure for all diseases and he sprayed it on his bed, clothes, beard, hair, floor, walls and before leaving to visit somebody, he applied both turpentine and cologne onto his hands and called it "Bouquet Solovieff" in jest... Many times his friends warned him against the turpentine misuse but he was extremely stubborn relating to that" (Velichko, 1902) "He paid with his life for demon clearing turpentine, having poisoned himself with turpentine" (Makovsky, 2000)

Those stories showed that great respect that the Russian people treated scientists with. Parody science contends that the author of the periodic system of D.I. Mendeleev became famous for his skillful "suitcase production". Once purchasing materials for making suitcases in the household items store, he heard such a conversation: "Who is that respectable gentleman?" - "Don't you know him? He is a renowned suitcase maker Mendeleev", said the salesperson with respect in his voice (Stepin, 1995)

Scientific thought of the Russian Empire last existence decades tried to break through the world level. In order to become a full-fledged member of those system relations, it lacked a little thing - intellectual property rights for scientific discoveries and full-fledged world recognition. A remarkable Russian naturalist, founder of the Russian and British plant physiology schools K.A. Timiryazev(1843 - 1920) wrote: "Take any book of the foreign scientific journal and you for sure will see a Russian name there" (Timiryazev, 1926). The Russian scientists in those years received world recognition quite often. The same K.A. Timiryazev was professor of Moscow University, Corresponding Member of Russian Academy of Sciences (1890) and member of the London Royal Society (since 1911), Honorary Doctor of Cambridge University, Geneva and Glasgow universities.

However, the other side of the story is the problem of recognition of the priority in the scientific discovery. By the example of D.I. Mendeleev and A.S. Popov we see that the Russian learned elite appeared to be not competitive as a result of inadequate scientific tradition development in Russian and low public demand for the science outcomes. As a result, much was lost and wasted. The Russian Empire's learned elite lacked system concentration. The last representatives of the imperial learned elite were popularized only in the Soviet time (I.P. Pavlov, K.A. Timiryazev, I.V. Michurin, E.K. Tsiolkovsky, V.I. Vernadsky). Some scientists were repressed and persecuted (B.M. Bekhterev, N.I. Vavilov, P.A. Florensky, P.N. Savitsky, L.N. Gumilyov, etc.), many had to emigrate (N.A. Berdyaev, P.A. Sorokin, I.P. Prigozhin, etc.) or become assets of the foreign scientific societies. Philosophers' ship had become a symbol of elite minds expel from Russia (Makarov, Khristoforov, 2003). Thousands of talented scientists and engineers found themselves in emigration: I.I. Sikorsky [designed the first in the world multi-engine plane and the first in the world helicopter], V.K. Zvorykin [designed the first in the world television set], S.M. Prokudin-Gorsky [created the first in the world colour photograph], K.M. Verigin [created Chanel No.5 perfume], M.M. Strukov [designed the first jet military transport plane in the USA], V.V. Leontyev [is the most renowned $20^{\text {th }}$ century US economist], etc.

No any other country in the world history have seen such intellectual dissipation. The end is grievous but not for the history of the imperial learned elite left their traces on world history pages.

The attitude of the western scientific community to the Russian science is vividly seen in the case of D.I. Mendeleev. It is knownthat he was three times Nobel Prize nominee (in 1905, 1906 and 1907) and he failed - the preference was given to more famous foreign scientists who are hardly remembered nowadays. In 1907 D.I. Mendeleev was selected as a winner but on February 2 he died. Many people then remembered the conflict of D.I. Mendeleev with Nobel brothers (over 1880s) who took advantage of the oil industry crisis and trying to monopolise Baku oil extraction and refining were profiteering with "intrigue breathing speculations" on oil depletion. D.I. Mendeleev proved the reverse and 
appeared to be absolutely right. They are still extracting oil in Baku having forgot L.E Nobel's accusation in destructive hydrocarbons consumption (Blokh, 2002).

\section{Concluding Remarks}

The analysis conducted by usproves that the Russian science attained the world-scale level. It was equal to the advanced foreign science and it was successfully integrating in its intellectual space and was a co-author of numerous scientific projects. However, murderous events of the Russian revolution put an end to science structural development. Researchers not having left Russia for several decades made fame and pride of their country. Revolutionary disturbances brought backward the development of the scientific thought. The scientific life was interrupted by the ideological factor and Stalin's repression grindstones killed many outstanding scientists who are now considered to be Russian science pride. We can say that the development of science was broken at the very peak of its potential. University traditions, scientific schools and achievements were scattered by the revolutionary vortex and it took decades to restore its previous authority and bring the Russian science back in the world science.

\section{References}

Blok L. D. (1987) Classical Dance: History and the Present. Foreword of V. Gaevsky. M.: Iskusstvo,. - 556 p.

Blokh A.M. (2002) "Nobeliana"of Dmitry Mendeleev. Priroda. No.2, 2002.

Velichko V.L. (1902). Vladimir Solovyov. Life and Creations. St. Petersburg: printR. Golike, 205 p.

Vitte S.Yu. (1994) Memoirs: in 3 vol.. 1: 1849-1894 Childhood. Alexander II andAlexander III reign foreword of A. V. Inatyev. Tallinn; M.:Skif Alex, $528 \mathrm{p}$.

Vitte S.Yu. (1994) Memoirs: in 3 vol. 2: 1894-1905 Nikolas II Regn. Tallinn; M.:Skif Alex, 576 p.

Polovtsov A.A. (2005) Diary of the State Secretary: in 2 vol. M.: Tsentrpoligraf, 603 p.

Memoirs of Prince Peter Dolgorukov (2007). Trans. From French of A.Yu.Serebryannikova; foreword, notes and index of S.N. Iskul. St.Petersburg: Publishing Centre Gumanitarnaya Academia, $640 \mathrm{p}$.

Kostanyan Yu. L. (2005) Count Mikhail Tarielovich Loris-Melikov. St. Petersburg, 234 p.

Kropotkin P.A. (1966) Revolutionary's Memoirs. M.: Mysl, p.113-114.

Kropotkin P.A. (1876) Glacial Age Investigations. St. Petersburg, 827 p. (Letters of IRGO in General Geography; V.7)

Lyashenko L. (2012) "Velvet Dictator". How Mikhail Loris-Melikov Suppressed the Revolution with the Liberal Reforms. The Moscow News of 14.03.2012.

Makarov V.G., Khristoforov V.S. (2003) Passengers of the "Philosophic Ship" (destiny of the intelligentsia repressed in SummerAutumn1922). Issues of Philosophy. No. 7, p.113-137.

Makovsky S. K. (200) At the Parnassus of the Silver Age. M.: XXI Century-Soglasie, p.560.

Maslin M.A. (1997) S.N. Trubetskoy as a Russian Philosopherp.3-14. Trubetskoy S.N. History of Ancient Philosophy. M.: VLADOS; Russkiy Dvor, $576 \mathrm{p}$.

Serpokry I.S. (1969) Prisoners of Peter-and-Paul Fortress. L.: Lenizdat, 440 p.

Spendel D. (2007) Female Builders of Strings. A Woman, Creativity, Literature. St. Petersburg: St. Petersburg-XXI Century

Stepin B. D., Alibekova L. Yu. (1995) A Book in Chemistry for Home Reading. $2^{\text {nd }}$ edition.M.: Khimiya

Timiryazev K.A. (1926) Science and Democracy. Collected Articles 1904 - 1919. Leningrad: Priboy, 432 p.

Shilov D.N. (2002) Public Figures of the Russian Empire. St. Petersburg. 